\title{
CHARACTERIZATION OF RED MUD/METAKAOLIN-BASED GEOPOLYMERS AS MODIFIED BY $\mathrm{Ca}(\mathrm{OH})_{2}$
}

\author{
KARAKTERIZACIJA GEOPOLIMEROV NA OSNOVI ZMESI \\ RDEČEGA BLATA IN METAKAOLINA, MODIFICIRANIH S \\ $\mathrm{Ca}(\mathrm{OH})_{2}$
}

\author{
Ivana Bošković ${ }^{*}$, Mira Vukčević1, Snežana Nenadovićé, Miljana Mirković2, \\ Marija Stojmenović ${ }^{2}$, Vladimir Pavlović ${ }^{3}$ and Ljiljana Kljajević ${ }^{2}$ \\ ${ }^{1}$ Faculty of Metallurgy and Technology, University of Montenegro, Cetinjski put bb, 81000 Podgorica, Montenegro \\ ${ }^{2}$ Laboratory for Materials Sciences, Institute of Nuclear Sciences Vinča, Mike Petrovića Alasa 12-14, Vinča, 11000 Belgrade, Serbia \\ ${ }^{3}$ Institute of Technical Sciences of the Serbian Academy of Sciences and Arts, Knez Mihailova 35/IV, 11000 Belgrade, Serbia
}

Prejem rokopisa - received: 2018-06-29; sprejem za objavo - accepted for publication: 2018-12-13

doi: $10.17222 / \mathrm{mit} .2018 .130$

\begin{abstract}
Geopolymers are an emerging class of materials that offer an alternative to the Portland cement as the binder of structural concrete. One of the advantages is that the primary source of their production is waste alumosilicate materials from different industries. One of the key issues in geopolymer synthesis is the low level of mechanical properties due to porosity as well as the high activity of conductivity carriers. It can often lead to limited application possibilities, so the objective is to obtain an enhanced strength as well as decreased cracking tendency through microstructure modification. The introduction of $\mathrm{Ca}(\mathrm{OH})_{2}$, under certain $\mathrm{pH}$ conditions could lead to the filling-the-pores process and improving the mechanical properties. The aim was to understand the role that calcium plays in the geopolymer synthesis, and to define which reaction prevails under the synthesis conditions: formation of geopolymer gel or calcium silicate hydrate that contains aluminum substitution (CASH). The synthesis was performed with different raw materials (with or without red mud) and different alkalinity conditions. $\mathrm{Ca}(\mathrm{OH})_{2} \mathrm{was}$ the obligatory supplement to both of the mixtures. Different techniques were performed for the testing of reaction products, as well as to define the microstructural changes as the generator of improved mechanical properties and changed electrical conductivity. The characteristics of the geopolymer's macrostructure were defined by means of an SEM analysis. Compressive strength and electrical conductivity are among the investigated product's properties. X-ray diffraction (XRD) and Fourier transform infra-red spectroscopy (FTIR) were used for the identification of various crystalline phases and an amorphous phase.

Keywords: geopolymers, compressive strength, calcium hydroxide, electrical conductivity
\end{abstract}

Geopolimeri so nova obetavna vrsta materialov, ki kot vezivo strukturnega betona predstavljajo alternativo Portlandskemu cementu. Ena od njihovih prednosti je, da so primarni vir za njihovo proizvodnjo odpadni alumosilikatni materiali iz različnih industrij. Ključno pri sintezi geopolimerov je njihov nizek nivo mehanskih lastnosti zaradi poroznosti, kakor tudi visoka aktivnost nosilcev prevodnosti. Visoka aktivnost lahko često privede do omejitev pri njihovi uporabnosti. Tako je glavni cilj sinteze geopolimerov visoka trdnost in majhna tendenca pokanja, kar naj bi dosegli z modifikacijo mikrostrukture. Uvajanje $\mathrm{Ca}(\mathrm{OH})_{2}$ pri določeni $\mathrm{pH}$ vrednosti lahko privede do procesa zapolnitve por in s tem izboljšanja mehanskih lastnosti. Namen pričujočega prispevka je bil razumeti vlogo kalcija v sintezi geopolimerov, kakor tudi definiranje reakcij, ki prevladujejo pri danih pogojih sinteze: tvorba geopolimernega gela in, ali kalcijev-silikatni hidrat vsebuje nadomestek za aluminij (CASH). Avtorji so sintezo izvedli z različnimi surovinami (z rdečim blatom, ali brez njega) in pri različnih pogojih bazičnosti. Obvezno so $\mathrm{Ca}(\mathrm{OH})_{2}$ dodajali obema mešanicama. Uporabili so različne tehnike testiranja reakcijskih produktov, kakor tudi za definiranje mikrostrukturnih sprememb, ki so generator izboljšanja mehanskih lastnosti in spremenjene električne prevodnosti. Makrostrukturo geopolimerov so ovrednotili z SEM analizo. Kot glavni lastnosti preiskovanih produktov so določili njihovo tlačno trdnost in električno prevodnost. Rentgensko strukturno analizo (XRD) in Furierjevo transformacijsko infrardečo spektroskopijo so uporabili za indentifikacijo različnih kristaliničnih in amorfnih faz.

Ključne besede: geopolimeri, tlačna trdnost, kalcijev hidroksid, električna prevodnost

\section{INTRODUCTION}

Aluminosilicate inorganic polymers, also called geopolymers, are materials formed under high alkali conditions from aluminosilicate solid and alkali silicate solutions. ${ }^{1}$ Geopolymers are produced from natural raw alumino-silicate materials and unconventional materials such as industrial and natural wastes. ${ }^{1-8}$ Metakaolin as a dehydroxylation product of the industrial mineral kaolin as well as red mud from the alumina production process are recognized as such. Red mud is a highly alkaline,

*Corresponding author e-mail:

ivabo@ucg.ac.me aluminosilicate-containing by-product of alumina production. Potential reuse of this waste as the precursor for new class of materials is highly welcomed as the eco-friendly solution of the large open disposals. Both metakaolin and red mud can be used in the process of alkaline activation as the inorganic precursors mainly constituted of silica, alumina and a low content of calcium oxide. Unlike other industrial processes (e.g., sol-gel, clinkerization, sintering processes), the alkali activation process does not require expensive chemical reagents, use of carbonate-based raw materials or high temperature thermal treatments. ${ }^{9}$ 
The basic part of the geopolymerization process is hardening, which is the base for the polycondensation of alkali precursors formed through the dissolution of active silicates and aluminosilicate solid materials in alkali hydroxide. The polymeric network as the result of polycondensation process hardens rapidly acting as the gluing component. ${ }^{1}$ These are materials with the crosslinked long inorganic chain between tetrahedral $\mathrm{AlO}_{4}$ and $\mathrm{SiO}_{4}$ units built in three dimensional structures having good compressive strength, corrosion resistance, resistance to extreme temperatures. The potential weakness lies in the increased porosity, which depends on synthesis and curing conditions. Porosity can be lowered by the modification of microstructure provoking the filling-of-pores-mechanism by inorganic or organic modificators of the microstructure. In the aluminosilicate geoploymer materials, the $\mathrm{M}^{+}$, water molecule and hydroxyl are the most important factors to influence electrical conductivity and dielectric property at room temperature. The existent way of alkali ion $\mathrm{M}^{+}$in the molecular structure of geopolymer materials is not theoretically clear. Usually, the accustomed viewpoint is that the alkali metal ions play a charge-balancing role or are actively bonded into the matrix; hence the typical geopolymer composition is expressed as $n \mathrm{M}_{2} \mathrm{O} \cdot \mathrm{Al}_{2} \mathrm{O}_{3}$. $x \mathrm{SiO}_{2} \cdot y \mathrm{H}_{2} \mathrm{O} .{ }^{9-11}$

\section{EXPERIMENTAL PART}

The following materials have been used in the process of geopolymer synthesis:

- red mud from the alumina factory KAP Podgorica,

Montenegro (whose chemical content is shown in

Table 1.

Table 1: Chemical composition of red mud from Alumina factory KAP Podgorica

\begin{tabular}{|c|c|c|c|c|c|c|}
\hline Oxide & $\mathrm{SiO}_{2}$ & $\mathrm{Fe}_{2} \mathrm{O}_{3}$ & $\mathrm{Al}_{2} \mathrm{O}_{3}$ & $\mathrm{TiO}_{2}$ & $\mathrm{Na}_{2} \mathrm{O}$ & $\mathrm{CaO}$ \\
\hline wt \% & 11.28 & 40.78 & 17.91 & 10.20 & 6.9 & 1.5 \\
\hline
\end{tabular}

- sodium hydroxide of analytical grade (Merck),

- metakaolin, obtained by the calcination of kaolin at $650{ }^{\circ} \mathrm{C}$ for $2 \mathrm{~h}$ (commercial product used in the production of welding electrodes Factory FEP, Montenegro), whose chemical content is shown in Table 2 .

Table 2: Chemical composition of metakaolin obtained by calcination of kaolin

\begin{tabular}{|l|l|l|l|l|l|l|l|l|l|}
\hline Oxide & $\mathrm{SiO}_{2}$ & $\mathrm{Fe}_{2} \mathrm{O}_{3}$ & $\mathrm{Al}_{2} \mathrm{O}_{3}$ & $\mathrm{MgO}$ & $\mathrm{Na}_{2} \mathrm{O}$ & $\mathrm{CaO}$ & $\mathrm{K}_{2} \mathrm{O}$ & $\mathrm{TiO}_{2}$ & $\mathrm{ZnO}$ \\
\hline
\end{tabular}

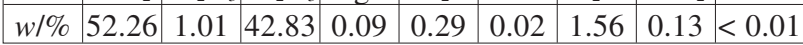

- sodium-silicate solution $\left(\right.$ Merck $\mathrm{Na}_{2} \mathrm{O}: \mathrm{SiO}_{2}=3.4$, $\mathrm{Na}_{2} \mathrm{O} 7.5-8.5 \%, \mathrm{SiO}_{2} 25.5-28.5 \%$ and $d=1.347$ $\mathrm{g} \mathrm{c}^{-3}$ ).

Two different raw mixtures were used in this research: metakaolin $(80 w / \%)$, red mud $(15 w / \%)$ and
$\mathrm{Ca}(\mathrm{OH})_{2}(5 w / \%) ; \mathrm{Si} / \mathrm{Al}$ mass ratio $=1.48$ (the sample marked as GPRM) as well as metakaolin (95 w/\%) and $\mathrm{Ca}(\mathrm{OH})_{2}(5 w / \%) ; \mathrm{Si} / \mathrm{Al}$ mass ratio $=2.36$ (the sample marked as GPM).

The other relevant process parameters (concentration of liquid-phase components) were as follows: $\mathrm{c}(\mathrm{NaOH})$ $=4 \mathrm{~mol} \mathrm{dm}^{-3}$ and $8 \mathrm{~mol} \mathrm{dm}^{-3}$; mass ratio $\mathrm{Na}_{2} \mathrm{SiO}_{3} / \mathrm{NaOH}$ $=2.5$; mass ratio $S / L=1.45$.

The specimens were molded into the cylindrical containers $(d=33 \mathrm{~mm} ; H=17 \mathrm{~mm})$, keeping closed at $25{ }^{\circ} \mathrm{C}$ for a duration of $3 \mathrm{~h}$, followed by drying of the specimens at $60{ }^{\circ} \mathrm{C}$ for a duration of $2 \mathrm{~h}$ as well as air aging of the closed-in-mold specimens for a duration of $24 \mathrm{~h}$. The open-mold-specimen specimens were aged for $(7,14,21$ and 28) d.

All the synthesized samples were characterized by $\mathrm{X}$-ray diffraction analysis (XRD) using an Ultima IV Rigaku diffractometer, equipped with $\mathrm{Cu}-\mathrm{K} \alpha_{1,2}$ radiation, with a generator voltage of $40.0 \mathrm{kV}$ and a generator current of $40.0 \mathrm{~mA}$. The $2 \theta$ range of $5-80^{\circ}$ was used for all powders in the continuous scan mode with a scanning step of $0.02^{\circ}$ at a rate of $5 \% \mathrm{~min}$.

The functional groups of all considered samples were studied using FTIR spectroscopy. Samples were powdered finely and dispersed evenly in anhydrous potassium bromide $(\mathrm{KBr})$ pellets $(1.5 \mathrm{mg} / 150 \mathrm{mg} \mathrm{KBr})$. Spectra were taken at room temperature using a Bomem (Hartmann \& Braun) MB-100 spectrometer set to give undeformed spectra.

The microstructure analysis was performed on Au-coated samples using a JEOL JSM 6390 LV electron microscope at $25 \mathrm{kV}$ coupled with EDS (Oxford Instruments $\mathrm{X}-\mathrm{Max}^{\mathrm{N}}$ ).

The $\mathrm{HCl}$ extraction was used to remove both geopolymer gel and CSH and to monitor the amount of reaction products (both geopolymer and $\mathrm{CSH}$ gel). Geopolymer was attacked with $37 \% \mathrm{HCl}$ solution (1:20, by volume). For every $1 \mathrm{~g}$ of sample $250 \mathrm{~cm}^{3}$ of $\mathrm{HCl}$ solution was added. The mixture was stirred for three hours and filtered. Insoluble residue was dried at $100{ }^{\circ} \mathrm{C}$ for $24 \mathrm{~h}$ and weighed.

The compressive strength of the tested samples was determined after $28 \mathrm{~d}$ air aging at room temperature. Test was performed on a HPN400 type press (ZRMK-Ljubljana).

The electrical properties of the sintered samples were measured by complex impedance method, in a frequency range $10 \mu \mathrm{Hz}$ to $1 \mathrm{MHz}$, using Interface 1000 Potentiostat/Galvanostat / ZRA and EIS300 Electrochemical Impedance Spectroscopy Software. The measurements were conducted in air, in the temperature range 300-700 ${ }^{\circ} \mathrm{C}$, with a $50{ }^{\circ} \mathrm{C}$ increment. 


\section{RESULTS AND DISCUSSION}

\subsection{XRD analysis}

The XRD analysis of red mud (Figure 1) shows the presence of hematite $\mathrm{Fe}_{2} \mathrm{O}_{3}$, gibbsite $\mathrm{Al}(\mathrm{OH})_{3}$, akdalaite $\left(\mathrm{Al}_{2} \mathrm{O}_{3}\right)_{4} \cdot \mathrm{H}_{2} \mathrm{O}$, lepidocrocite $\mathrm{FeO}(\mathrm{OH})$ and calcite $\mathrm{CaCO}_{3}$.

Figure 2 shows the XRD patterns of the geopolymer samples GPRM1 (a), GPRM2 (b), GPM1 (c), GPM2 (d) $\left(\mathrm{GPRM} 1-\mathrm{c}(\mathrm{NaOH})=4 \mathrm{~mol} \mathrm{dm}{ }^{-3}\right.$, GPRM2-c $(\mathrm{NaOH})=$ $8 \mathrm{~mol} \mathrm{dm}^{-3}$, GPM1-c $(\mathrm{NaOH})=4 \mathrm{~mol} \mathrm{dm}^{-3}$, GPM2-c $\left.(\mathrm{NaOH})=8 \mathrm{~mol} \mathrm{dm}^{-3}\right)$. According to the identified XRD

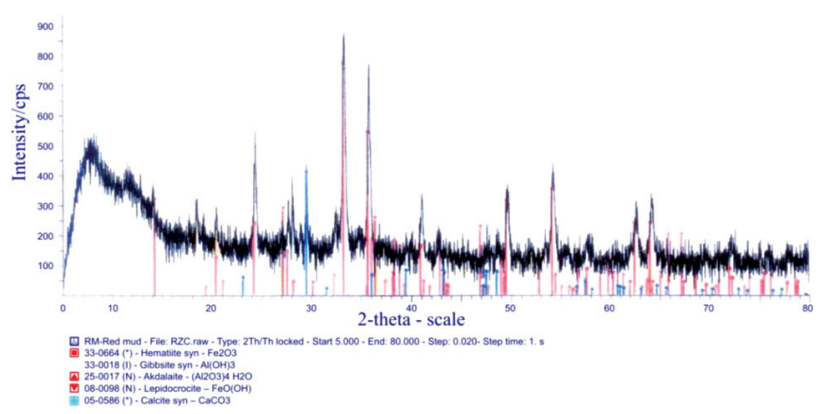

Figure 1: XRD analysis of red mud from KAP Podgorica
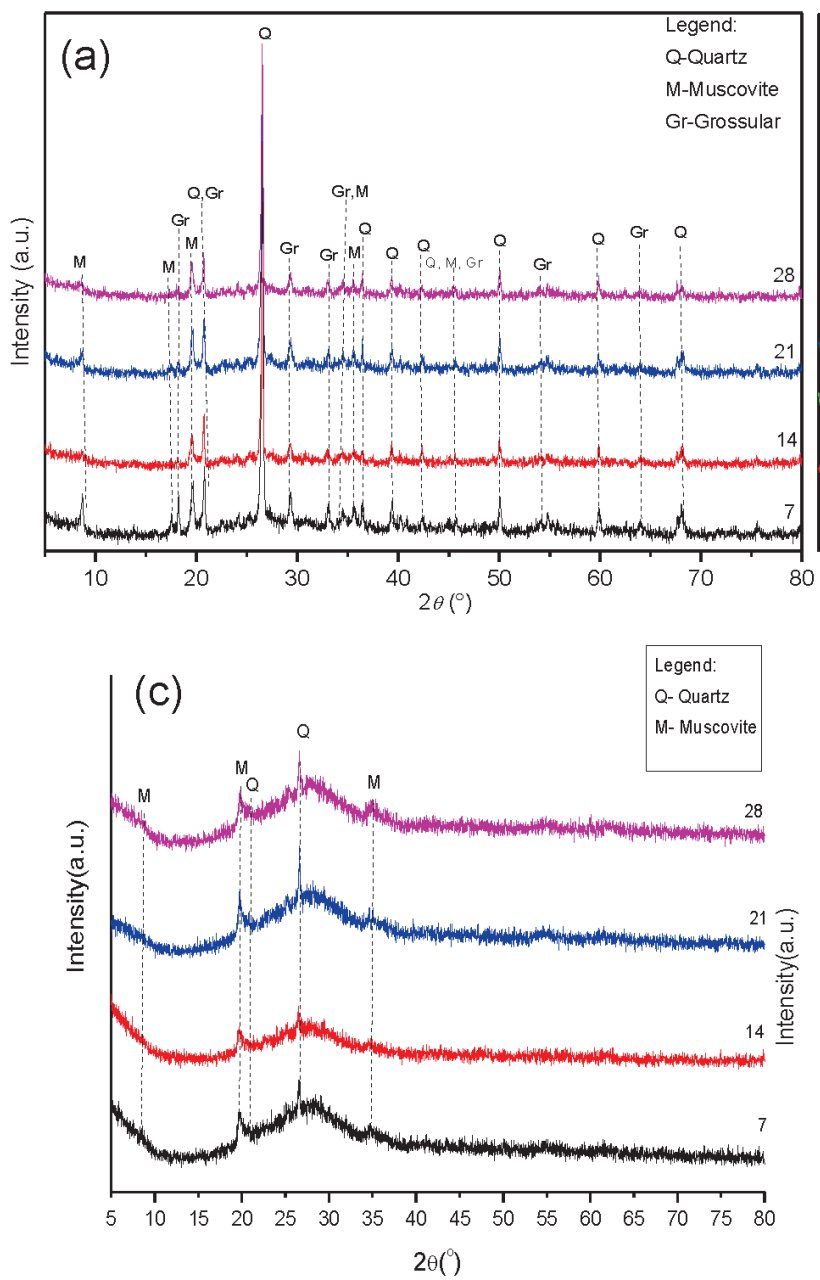

patterns the mineral phases identified in the GPRM1 are muscovite, quartz, and grossular. Also, for sample GPRM2 muscovite and quartz appeared, but new phases gibbsite and acmite were also found. The difference in the mineral composition of these two geopolymer samples may be due to different composition of starting materials, red mud or metakaolin. In these samples a hump which is characteristic for geopolymer materials is poorly expressed and only appeared for samples which are aged for $7 \mathrm{~d}$. The structure of the geopolymers samples GPRM1 and GPRM2 are ordered with time because of the high presence of crystalline phases. The hump which is an indicator of amorphousness disappears. The intensity of other peaks with aging time is increased (Figure 2a and Figure 2b).

According to the identified XRD patterns the mineral phases identified in the GPM1 and GPM2 are muscovite and quartz (Figure 2c and Figure 2d). XRD analysis of these geopolymer samples revealed their amorphous-like structure with the position of an amorphous halo in the range $22^{\circ}-35^{\circ}$, which indicate short range ordering of both samples with crystalline admixture of $\mathrm{SiO}_{2}$ $(\alpha$-quartz). The hump that appears in the XRD patterns

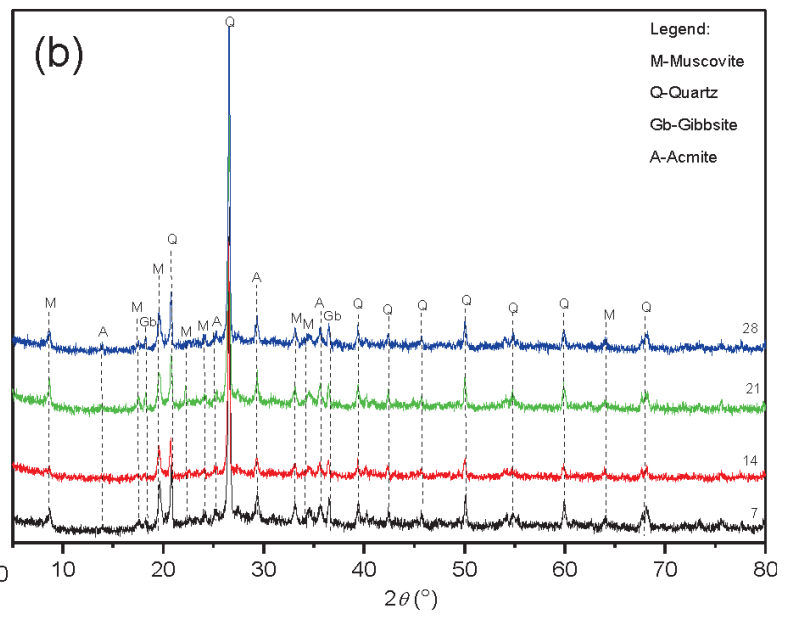

(d)

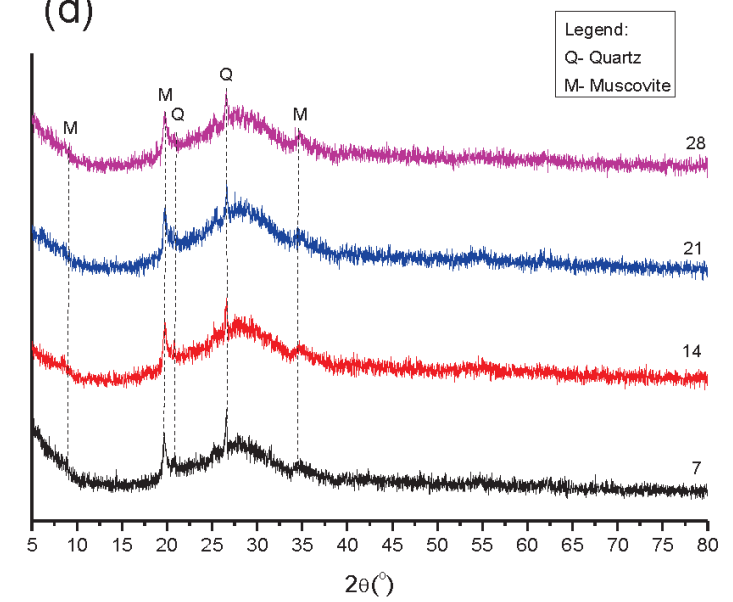

Figure 2: XRD patterns of the geopolymer samples: a) GPRM1, b) GPRM2, c) GPM1 and d) GPM2 
of the GPM sample is sharper when in the geopolymerization reaction there was a higher molarity of $\mathrm{NaOH}$.

\subsection{FTIR analysis}

FTIR analysis was done for samples that were aged at room temperature for $28 \mathrm{~d}$ in open molds. FTIR analysis of aforementioned specimens is shown on Figure 3 and Figure 4.

The major bands were a broad band at $3000-3500 \mathrm{~cm}^{-1}$ (in our case, the maximum band width ranges $\approx 3450 \mathrm{~cm}^{-1}$ ) and $1638 \mathrm{~cm}^{-1}$, which represent the stretching and deformation vibration of $\mathrm{OH}$ and $\mathrm{H}-\mathrm{O}-\mathrm{H}$ groups from water molecules. These absorptions have been attributed to both atmospheric and bound water in geopolymers. ${ }^{10,11}$ The bands at $1424 \mathrm{~cm}^{-1}$ and $878 \mathrm{~cm}^{-1}$ point to carbonate presence..$^{12}$ This is probably caused by the reaction of atmospheric $\mathrm{CO}_{2}$ with calcium hydroxide (band at $\approx 878 \mathrm{~cm}^{-1}$ ) (sample GPRM1 and sample GPRM2). Some authors reported that geopolymers are focused on the behavior of $\mathrm{Si}-\mathrm{O}-\mathrm{Si}$ and $\mathrm{Si}-\mathrm{O}-\mathrm{Al}$ bands. ${ }^{10-13}$ Taking a straightforward approach, the identification of the position of the main $\mathrm{Si}-\mathrm{O}-\mathrm{T}(\mathrm{T}=\mathrm{Si}$ or $\mathrm{Al})$ asymmetric stretching vibration (the strongest band) is here defined as the point of maximum absorbance in the region $1250-950 \mathrm{~cm}^{-1}$ and at $420-500 \mathrm{~cm}^{-1}$. These peaks will be referred to as the "main band" in the spectrum of the geopolymers. The main broad band at $1030 \mathrm{~cm}^{-1}$ corresponding to asymmetric stretching vibrations of $\mathrm{Si}-\mathrm{O}-\mathrm{Si}$ and Al-O-Si shifts toward lower frequencies related to precursor materials (red mud/metakaolin) as a result of the formation of new reaction products associated with ongoing alkali activation. The bands located at $794 \mathrm{~cm}^{-1}$ and $778 \mathrm{~cm}^{-1}$ are ascribed to bending vibrations of $\mathrm{Si}-\mathrm{O}-\mathrm{Si}$ and $\mathrm{O}-\mathrm{Si}-\mathrm{O}$ bonds, implying the presence of quartz that is hardly affected by alkaline activation of precursors. Moreover, in both GPRM spectra, peak due to stretching vibrations of the Fe-O (460-560 $\mathrm{cm}^{-1}$ range) was also present. ${ }^{14}$ Due to the symmetric stretch of the Si-O-Al framework, an additional peak in the position at $692 \mathrm{~cm}^{-1}$ (Figure 3) was observed.

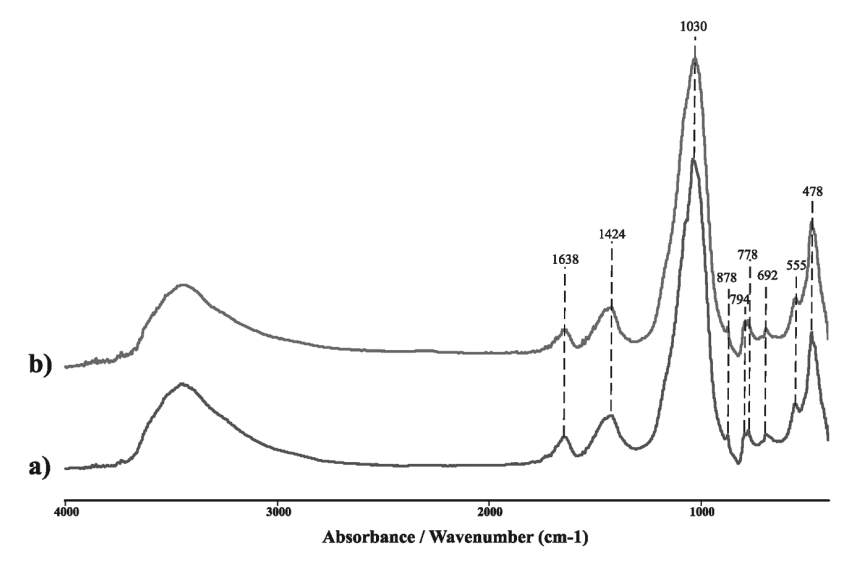

Figure 3: FTIR spectra: a) GPRM1, b) GPRM2

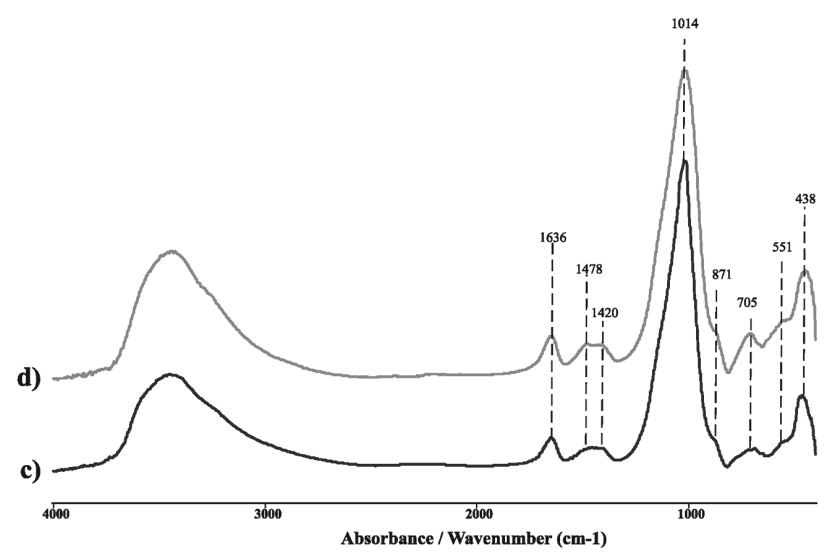

Figure 4: FTIR spectra: c) GPM1, d) GPM2

For the GPM1 and GPM2 samples there are differences in the characteristic band position in relation to the previous samples (Figure 4). All the band positions corresponding to the above are shifted to smaller wave numbers. A shift of the Si-O-X stretching band towards lower wave numbers indicates lengthening of the $\mathrm{Si}-\mathrm{O}-\mathrm{X}$ bond, reduction in the bond angle, and thus a decrease of the molecular vibrational force constant. ${ }^{15}$ In our case the shift of the Si-O-X stretching band is evident: its position is $1030 \mathrm{~cm}^{-1}$ for GPRM and $1014 \mathrm{~cm}^{-1}$ for GPM. Furthermore, the shifting of the wavenumber of the $\mathrm{Si}-\mathrm{O}-\mathrm{Si}$ stretching to the right (to a lower wavenumber) is indicative of the breaking of Si-O bonds and the formation of new $\mathrm{Si}$ bonds in the process of geopolymerization. ${ }^{16}$ In addition, new vibration band appear at $1478 \mathrm{~cm}^{-1}$. There are no registered vibration bands in the area $770-800 \mathrm{~cm}^{-1}$. Changes in the positions and intensities of the vibrating bands in these two systems confirm that new alumosilicate phases are generated and that there is a difference between them as a function of applied precursors (red $\mathrm{mud} /$ metakaolin and metakaolin).

\subsection{SEM analysis}

The microstructure of the obtained structures is presented in Figure 5. The microstructure of the sample GPRM1 (Figure 5a) reveals a relatively homogeneous matrix with a grained structure of the unreacted particle over the matrix surface. The sample obtained by activation with $8-\mathrm{M} \mathrm{NaOH}$ seems to have dispersed platy, different-in-shape-and-size particles (probably residual red mud or metakaolin) (Figure 5b).

Figure 5c and Figure 5d show SEM micrographs of

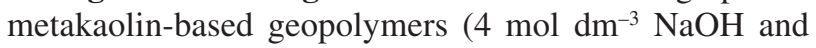
$8 \mathrm{~mol} \mathrm{dm}^{-3} \mathrm{NaOH}$ respectively). The surface of the GPM1 sample (Figure 5c) has a more homogeneous structure. The smaller particles are grouped along the surface of the agglomerated particles. The addition of $\mathrm{Ca}(\mathrm{OH})_{2}$ in the case with less molarity of $\mathrm{NaOH}$, allowed the formation of CSH gel. The GPM1 sample has the finest contours and surfaces indicative of the 

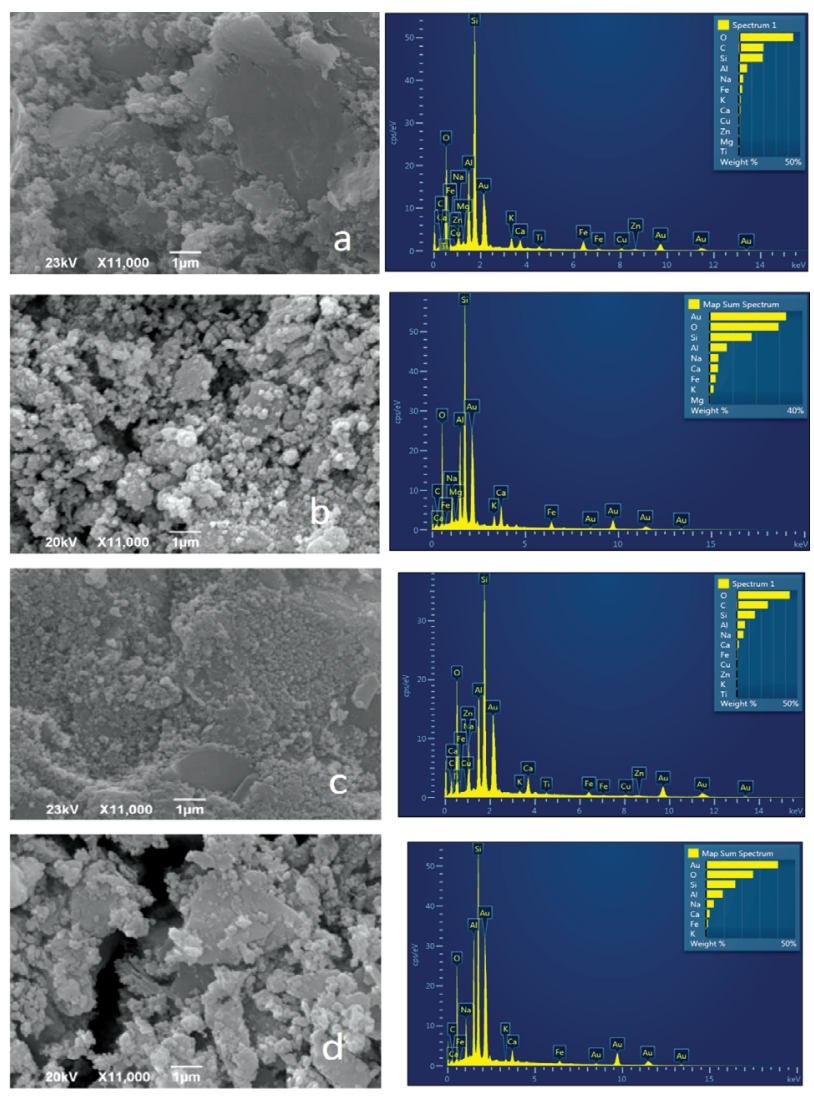

Figure 5: SEM micrographs and EDS analysis: a) sample GPRM1, b) sample GPRM2, c) sample GPM1 and d) sample GPM2

extent of dissolution and polycondensation that occurred during geopolymerization for this mixture.

The EDS spectra of all the geopolymer samples showed the presence of $\mathrm{Al}, \mathrm{Si}, \mathrm{Na}, \mathrm{Ca}, \mathrm{Mg}, \mathrm{K}, \mathrm{Fe}$ and $\mathrm{O}$. There is more $\mathrm{Fe}$ in the first two samples, because of the hematite in the red mud.

\subsection{Chemical extraction}

Hydrochloric acid extraction was used to dissolve the geopolymers. This extraction is a quantitative procedure in which the extraction measures the amount of reacted material (both geopolymer and $\mathrm{CSH}$ gel) and unreacted material in the sample. ${ }^{17}$ The remaining residue is a precursor (metakaolin). This method can also be combined with the extraction with salicylic acid/methanol extraction which removes the $\mathrm{CSH}$ phase. ${ }^{17}$
The amount retained from the $\mathrm{HCl}$ extraction varied with different $\mathrm{Si} / \mathrm{Al}$ ratios and accordingly different $\mathrm{pH}$. It was $34.89 w / \%$ when $\mathrm{Si} / \mathrm{Al}$ ratio was $1.48 w / \%$ and 7.14 w/\%, when $\mathrm{Si} / \mathrm{Al}$ was 2.36 . These results show that during $\mathrm{HCl}$ extraction more metakaolin formed geopolymer gel as the $\mathrm{Si} / \mathrm{Al}$ ratio increased, which corresponds to the finding that different values of $\mathrm{pH}$ generate different reactions (CSH forming under low alkalinity conditions) and geopolymer gel forming under the higher alkalinity conditions.

\subsection{Compressive strength}

Compressive strength values are shown in Table 3. It is observed that the compressive strength is higher for samples obtained with a lower concentration of $\mathrm{NaOH}$. In addition, the highest value is achieved in the case when metakaolin is used as the precursor.

Table 3: Compressive strength values of obtained geopolymers

\begin{tabular}{|c|c|c|}
\hline Specimen & $\begin{array}{c}\text { Specific density } \\
\left(\mathrm{g} \mathrm{cm}^{-3}\right)\end{array}$ & $\begin{array}{c}\text { Compressive } \\
\text { strength }(\mathrm{MPa})\end{array}$ \\
\hline GPRM1 & 2.507 & 13.26 \\
\hline GPRM2 & 2.503 & 7.17 \\
\hline GPM1 & 2.254 & 27.35 \\
\hline GPM2 & 2.217 & 9.02 \\
\hline
\end{tabular}

The presence of calcium affects the structure change as well as the compressive strength. It is assumed that in the presence of calcium, CSH gel is produced as the main product, resulting in a homogeneous structure and therefore the value of compressive strength is higher. In conditions of less alkalinity, higher compressive strength is obtained. Decreasing of the compressive strength at higher concentrations of $\mathrm{NaOH}$ is explained by the fact that the $\mathrm{pH}$ is high enough to result in the dissolution of silicon from the raw material and the dissociation of calcium hydroxide is prevented. Under such conditions there is not enough calcium in the system to form the calcium-silicate-hydrate (CSH) phase, but a geopolymer gel is formed as a major product.

Red mud does not affect favorably the compressive strength. The strength of the samples based on the red mud is smaller compared to the samples based on the metakaolin due to the presence of Fe and excess $\mathrm{Na}$ concentration in the red mud.

Table 4: The temperature dependence of total ionic conductivity $(\chi)$ of the synthesized GPRM and GPM samples

\begin{tabular}{|c|c|c|c|c|c|c|}
\hline Composition & $\begin{array}{c}\chi \\
\left(\Omega^{-1} \mathrm{~cm}^{-1}\right) \\
500{ }^{\circ} \mathrm{C}\end{array}$ & $\begin{array}{c}\chi \\
\left(\Omega^{-1} \mathrm{~cm}^{-1}\right) \\
550{ }^{\circ} \mathrm{C}\end{array}$ & $\begin{array}{c}\chi \\
\left(\Omega^{-1} \mathrm{~cm}^{-1}\right) \\
600{ }^{\circ} \mathrm{C}\end{array}$ & $\begin{array}{c}\chi \\
\left(\Omega^{-1} \mathrm{~cm}^{-1}\right) \\
650{ }^{\circ} \mathrm{C}\end{array}$ & $\begin{array}{c}\chi \\
\left(\Omega^{-1} \mathrm{~cm}^{-1}\right) \\
700{ }^{\circ} \mathrm{C}\end{array}$ & $E_{\mathrm{a}}(\mathrm{eV})$ \\
\hline GPRM1 & $3.22 \cdot 10^{-3}$ & $5.81 \cdot 10^{-3}$ & $6.23 \cdot 10^{-3}$ & $8.39 \cdot 10^{-3}$ & $9.15 \cdot 10^{-4}$ & 0.31 \\
\hline GPRM2 & $4.31 \cdot 10^{-3}$ & $6.53 \cdot 10^{-3}$ & $7.22 \cdot 10^{-3}$ & $8.63 \cdot 10^{-2}$ & $9.98 \cdot 10^{-4}$ & 0.26 \\
\hline GPM1 & $2.06 \cdot 10^{-4}$ & $3.87 \cdot 10^{-4}$ & $6.56 \cdot 10^{-4}$ & $8.2 \cdot 10^{-4}$ & $1.22 \cdot 10^{-4}$ & 0.47 \\
\hline GPM2 & $1.16 \cdot 10^{-4}$ & $3.12 \cdot 10^{-4}$ & $5.29 \cdot 10^{-4}$ & $7.57 \cdot 10^{-4}$ & $1.13 \cdot 10^{-4}$ & 0.48 \\
\hline
\end{tabular}




\subsection{Electrical conductivity}

The complex impedance method was used to study the electrical properties of solid electrolytes. ${ }^{18-20}$ Generally, this method enables obtaining information about the separate contribution of the bulk and the grain-boundary resistance, as well as electrode process. A typical Nyquist plot of electrolyte in the solid state consists of three semicircles: one semicircle at high and one semicircle at intermediate frequency (ascribed to bulk and grain boundary), and a third semicircle at low frequency (ascribed the electrode process contribution). ${ }^{21}$ For the high and intermediate frequency the semicircles are characteristic of two serially connected RC circuits (one resistive and one capacitive element bonded in a parallel arrangement), where was capacitive element being distributed (frequency dependent) one. Such an equivalent circuit with both constant ${ }^{22,23}$ and distributed capacitive elements was applied widely in the literature, related to the sintered ceramics. The high-frequency semicircle may be attributed to a parallel connection of the bulk resistance $\left(R_{\mathrm{b}}\right)$ of crystallite grains, and the geometric capacitance $\left(C_{g}\right)$ of the sample. The low-frequency semi-
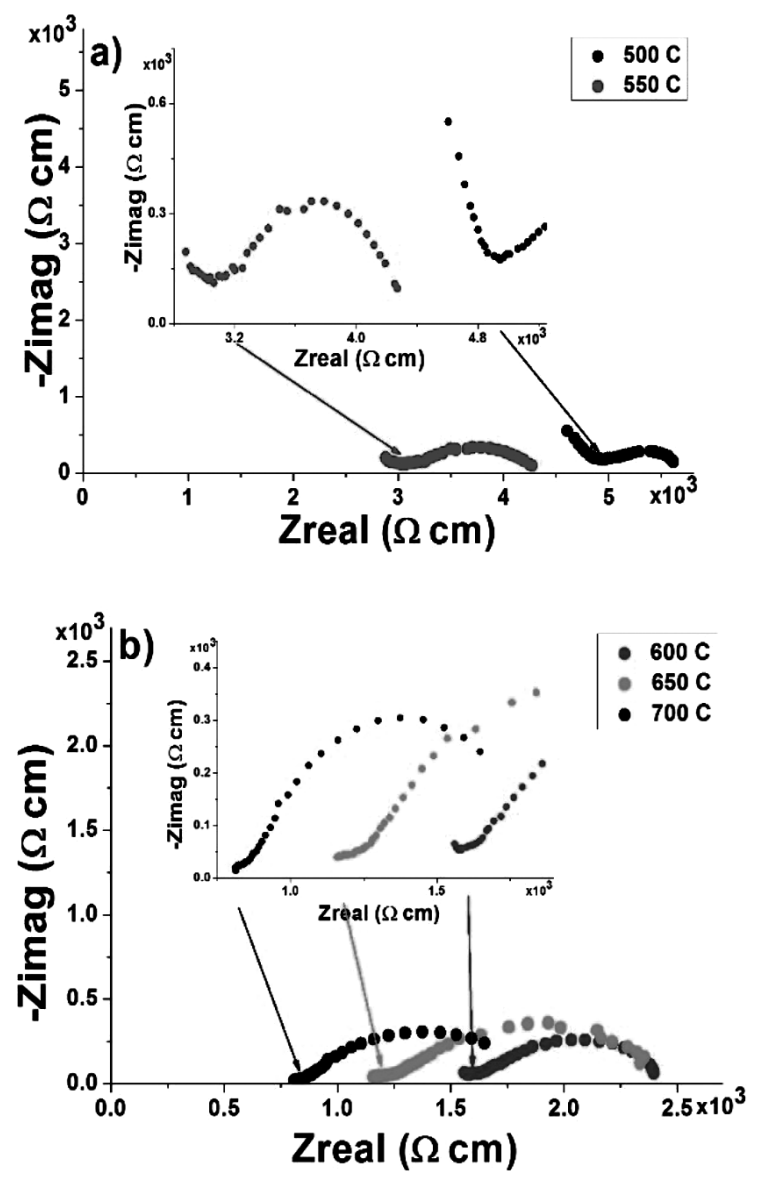

Figure 6: Complex impedance plots of the GPRM2 synthesized sample, measured at temperatures: a) $500-550{ }^{\circ} \mathrm{C}$ and b) $600-700{ }^{\circ} \mathrm{C}$, in air atmosphere. The working temperatures are indicated in each diagram. The arrows indicate the points on the real axis corresponding to the readings $R_{\mathrm{b}}$ and $R_{\mathrm{b}}+R_{\mathrm{ig}}$. circle may be attributed to the grain-boundary resistance $\left(R_{\text {ig }}\right)$ in parallel connection with the intergranular capacitance $\left(C_{\mathrm{ig}}\right)$. In this case, by means of the frequency which refers to the semicircle maximum, the intergranular capacitance can be calculated using the wellknown equation:

$$
w_{\text {max }, \mathrm{ig}}=\frac{1}{R_{\mathrm{ig}}} \cdot C_{\mathrm{ig}}
$$

In our work, the original Nyquist plots recorded in the available frequency range $(1 \mathrm{~Hz}-100 \mathrm{kHz})$ are presented in Figure 6. For the potential application in Intermediate-Temperature Solid-Oxide Fuel Cells (IT-SOFCs) the measurements of ionic conductivity of the electrolytes in solid state of the geopolymer based on red mud-metakaolin- $\mathrm{Ca}(\mathrm{OH})_{2}(\mathrm{GPRM})$ and metakaolin and $\mathrm{Ca}(\mathrm{OH})_{2}(\mathrm{GPM})$ were done in temperature range of 500-700 ${ }^{\circ} \mathrm{C}$, with increments of $50{ }^{\circ} \mathrm{C}$. As can be seen (Figure 6a and Figure 6b), with increasing the temperature, high and intermediate frequency semicircles disappear. At higher temperatures, the time constants associated with the bulk and grain-boundary impedances are much lower than those associated with the electrode interface. As a result, semicircles due to the bulk and grain-boundary disappear (Figure 6b) and only a single semicircle due to the electrode interfacial processes can be observed. In this case, only the whole sum $R_{\mathrm{b}}+R_{\mathrm{ig}}$ became readable and the values of the total resistance were estimated from the cross-section obtained semicircles with the real component of impedance $\left(Z_{\text {real }}\right)$.

This intercept is marked by arrows in Figure 6 (insets). New semicircles the formed in a low-frequency region, being particularly visible in temperature range $600-700{ }^{\circ} \mathrm{C}$ (Figure 6b), almost doubtless originates from the oxygen electrode reactions, $\mathrm{O}_{2} / \mathrm{O}^{2-}$, which does not belong to the scope of this study.

The values of the ionic conductivity of the synthesized samples are shown in Table 4. By comparing the obtained results, it can be noted that the highest values of ionic conductivity show the GPRM2 synthesized sample. The actual values of the total ionic conductivity of the mentioned sample at $700{ }^{\circ} \mathrm{C}$ amount to $0.0112 \Omega^{-1} \mathrm{~cm}^{-1}$. Additionally, comparing the obtained results of ionic conductivity with the literature data, ${ }^{24}$ it can be noted that the measured values are higher for the entire order of magnitude. More specifically, the values of ionic conductivity observed at $700{ }^{\circ} \mathrm{C}$ in this paper were similar to literature values obtained at $900{ }^{\circ} \mathrm{C}$. In addition, the conductivity of the samples measured in this study is similar to the literature data on similar oxygen ion conductor. ${ }^{19,24}$ It is assumed that in these materials the ionic conductivity occurs mainly via $\mathrm{O}^{-}$interstitials with preferential c-axis conduction, similar to $\mathrm{O}^{2-}$ vacancy migration in fluorite and perovskite-based electrolytes.

The temperature dependence of total ionic conductivity is given in Table 4 . 


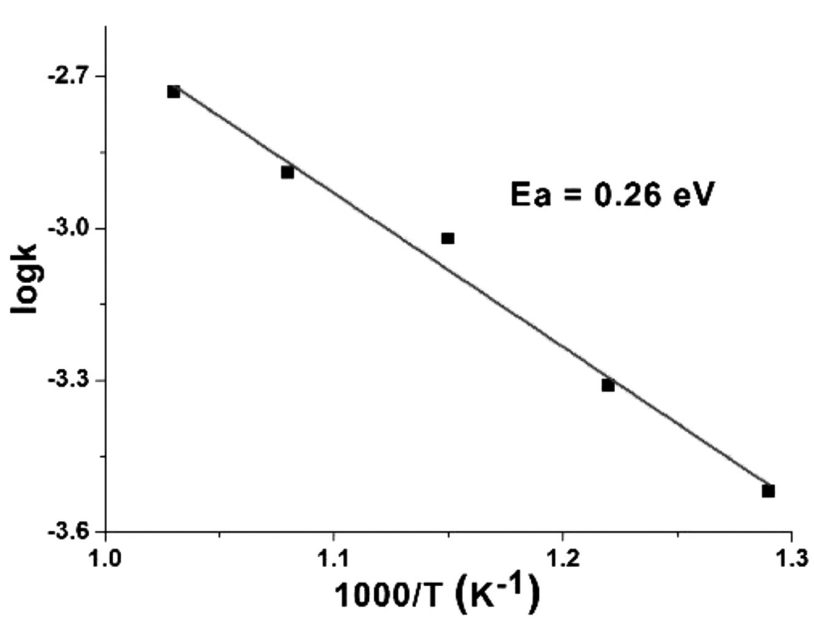

Figure 7: The dependence $\log \kappa=f(1 / T)$ of the synthesized sample GPRM2

According to the results of total ionic conductivity $(\chi)$ of the synthesized samples listed in Table 4 , the dependence $\log \kappa=f(1 / T)$ of the synthesized sample GPRM2 is presented in Figure 7. Activation energies $\left(E_{\mathrm{a}}\right)$ were calculated from Arrhenius plots according to the derived Equation (2):

$$
\ln (\sigma T)=\ln A-\left(\frac{E_{\mathrm{a}}}{k T}\right)
$$

The activation energy $\left(E_{a}\right)$ for the total conduction synthesized samples is presented in Table 4. The values of $E_{\text {a }}$ presented in our work are very low compared with the activation energy for similar ion conductors. ${ }^{18-24}$ It can be said that this is a consequence of a well-ordered structure and better processing of the obtained powders, which allows easier activation of conductivity carriers and decrease $E_{\mathrm{a}}$.

Thus, it must be pointed out that the impedance spectra measured at temperatures above $500{ }^{\circ} \mathrm{C}$ are reproducible, but several factors could affect the impedance measurements, such as incomplete contact between the sample and electrode, a short circuit through a less resistive path in the samples and the different presence of moisture in the samples. Especially, it should be emphasized that the significant improvements in conductivity are likely, which would lead to the very real possibility of the application of geopolymer-type electrolytes in fuel cell and other applications.

\section{CONCLUSIONS}

The presence of calcium affects the change of the structure as well as the compressive strength. In the presence of calcium in the geopolymerization product it is likely to have $\mathrm{CSH}$. The results of the $\mathrm{HCl}$ extraction showed that different values of $\mathrm{pH}$ generate different reactions ( $\mathrm{CSH}$ forming under low alkalinity conditions) and geopolymer gel forming under the higher alkalinity conditions.

Under the lower alkalinity conditions, the increased compressive strength is obtained. Higher alkalinity conditions do not favor the formation of $\mathrm{CSH}$, but the geopolymer gel. The results of the SEM analysis showed that the number of pores and cracks is much smaller for samples with lower alkalinity concentrations.

The compressive strength of the red-mud-based specimens is lower in comparison with the metakaolin specimens, and goes along with the weak evidence of the geopolymer formation. The highest value of compressive strength (27.35 $\mathrm{MPa})$ is achieved in the case when metakaolin is used as the precursor. The SEM analysis showed that the microstructure of that sample is almost completely homogeneous.

In post-curing aging treatment specimens with a lot of crystalline phases undergo the crystalline arrangement during this time. The amorphous response in the range of $2 \Theta=20-35^{\circ}$ does not show significant changes during the aging process of $28 \mathrm{~d}$. The addition of calcium has been observed to accelerate the hardening process.

FTIR spectra of two types of geopolymer samples (based on red mud and metakaolin and only on metakaolin) confirmed the formation of a new aluminosilicate phase and changes in the positions and intensities of vibrating bands due to different applied precursors.

As is well known, red mud has a high ionic concentration. In the case of the presence of moisture, conduction occurs through the spaces (pores and cracks) filled with water. The presence of $\mathrm{Na}^{+}, \mathrm{OH}^{+}, \mathrm{K}^{+}$ions in red mud which are highly conductive contribute to a higher conductivity when the sample loses moisture. Another factor is the higher porosity of the specimen containing red mud. This kind of structure allows easier activation of the conductivity carriers and decreases Ea. Without a deep insight into the microstructural features and a structural analysis that could shed light, the role of the different crystalline and amorphous phases responsible for the ionic conduction mechanism of ionic conductivity cannot be completely explained, but hypothesized.

\section{REFERENCES}

${ }^{1}$ A. Nazari, J. G. Sanjayan, Synthesis of geopolymer from industrial wastes, J. Clean. Prod., 99 (2015), 297-304, doi:10.1016/j.jclepro. 2015.03.003

${ }^{2}$ A. Kumar, S. Kumar, Development of paving blocks from synergistic use of red mud and fly ash using geopolymerization, Constr. Build. Mater., 38 (2013), 865-871, doi:10.1016/j.conbuildmat.2012.09.013

${ }^{3}$ Y. Nan et al., Synthesis and characterization of geopolymer from Bayer red mud with thermal pretreatment, J. Amer. Ceram. Soc., 97(5) (2014), 1652-1660, doi:10.1111/jace.12840

${ }^{4}$ M. Zhang T. El-Korchi, G. Zhang, J. Liang, M. Tao, Synthesis factors affecting mechanical properties, microstructure, and chemical composition of red mud-fly ash based geopolymers, Fuel, 134 (2014), 315-325, doi:10.1016/j.fuel.2014.05.058

${ }^{5}$ J. He, Y. Yu, J. Zhang, G. Zhang, The strength and microstructure of two geopolymers derived from metakaolin and red mud-fly ash 


\section{BOŠKOVIĆ et al.: CHARACTERIZATION OF RED MUD/METAKAOLIN-BASED GEOPOLYMERS ...}

admixture: a comparative study, Constr. Build. Mater., 30 (2012), 80-91, doi:10.1016/j.conbuildmat.2011.12.011

${ }^{6}$ D. Dimas, I. Giannopoulou, D. Panias, Utilization of alumina red mud for synthesis of inorganic polymeric materials, Min. Proc. \& Ext Met. Rev., 30(3) (2009), 211-239, doi:10.1080/ 08827500802498199

${ }^{7}$ J. He, J. Yuxin, J. Zhang, Y. Yu, G. Zhang, Synthesis and characterization of red mud and rice husk ash-based geopolymer composites, Cement Concrete Comp., 37 (2013), 108-118, doi:10.1016/ j.cemconcomp.2012.11.010

${ }^{8}$ H. Choo, S. Lim, W. Lee, C. Lee, Compressive strength of one-part alkali activated fly ash using red mud as alkali supplier, Constr. Build. Mater., 125 (2016), 21-28, doi:10.1016/j.conbuildmat. 2016.08.015

${ }^{9}$ K. Komnitsas, D. Zaharaki, Geopolymerization: A review and prospects for the minerals industry, Miner. Eng., 20 (2007) 14 1261-1277, doi:10.1016/j.mineng.2007.07.011

${ }^{10}$ E. Kamseu, I. Lancellotti, V. M. Sglavo, L. Modolo, C. Leonelli, Design of inorganic polymer mortar from ferricalsialic and calsialic slags for indoor humidity control, Mater. 9 (2016) 6, 410-428, doi: $10.3390 / \mathrm{ma} 9060410$

${ }^{11}$ C. Ferone, B. Liguori, I. Capasso, F. Colangelo, R. Cioffi, E. Cappelletto, R. Di Maggio, Thermally treated clay sediments as geopolymer source material, Appl. Clay Sci., 107 (2015), 195-204, doi:10.1016/j.clay.2015.01.027

${ }^{12}$ S. Nenadović, Lj. Kljajević, M. Nenadović, M. Mirković, S. Marković, Z. Rakocević, Mechanochemical treatment and structural properties of lead adsorption on kaolinite (Rudovci, Serbia), Environ. Earth Sci., 73 (2015), 7669-7677, doi:10.1007/s12665-014-3941-y

${ }^{13}$ Lj. Kljajević, S. Nenadović, M. Nenadović, N. Bundaleski, B. Todorović, V. Pavlović and Z. Rakočević, Structural and chemical properties of thermally treated geopolymer samples, Ceram. Int., 43 (2017) 9, 6700-6708, doi:10.1016/j.ceramint.2017.02.066

${ }^{14}$ S. Kumar, Eco-efficient masonry bricks and blocks, $1^{\text {st }}$ ed., Woodhead Publishing 2015, 311-328

${ }^{15}$ I. Bošković, M. Vukčević, M. Krgović, Role of binder in the process of geopolymerization of red-mud based products, J. Environ. Prot. Ecol., 4 (2015), 4-9
${ }^{16}$ S. Nenadović, Lj. Kljajević, M. Nešić, M. Petković, K.Trivunac, V. Pavlović, Structure analysis of geopolymers synthesized from clay originated from Serbia, Environ. Earth Sci., 79 (2017), 76, doi:10.1007/s12665-016-6360-4

${ }^{17}$ K. E. Heysung, Understanding effects of Silicon/Aluminum ratio and Calcium Hydroxide on chemical composition, microstructure and compressive strength for metakaolin geopolymers, Thesis, Graduate College, Department of Civil Engineering, University of Illinois 2012

${ }^{18}$ E. Pikalova, A. Murashkina, V. Maragou, A. Demin, V. Strekalovsky, P. Tsiakaras, $\mathrm{CeO}_{2}$ based materials doped with lanthanides for applications in intermediate temperature electrochemical devices, Int. J. Hydrogen Energy, 36 (2011) 10, 6175-6183, doi:10.1016/ j.ijhydene.2011.01.132

${ }^{19}$ H. Bae, J. Choi, G. Choi, Electrical conductivity of Gd-doped ceria film fabricated by aerosol deposition method, Solid State Ionics, 236 (2013), 16-21, doi:10.1016/j.ssi.2013.01.022

${ }^{20}$ J. Jiang, W. Shen, J. L. Hertz, Structure and ionic conductivity of nanoscale gadolinia-doped ceria thin films, Solid State Ionics, 249-250 (2013), 139-143, doi:10.1016/j.ssi.2013.08.003

${ }^{21}$ M. Kahlaoui, S. Chefi, A. Inoubli, A. Madani, C. Chefi, Synthesis and electrical properties of co-doping with $\mathrm{La}^{3+}, \mathrm{Nd}^{3+}, \mathrm{Y}^{3+}$, and $\mathrm{Eu}^{3+}$ citric acid-nitrate prepared samarium-doped ceria ceramics, Ceram. Int., 39 (2013) 4, 3873-3879, doi:10.1016/j.ceramint.2012.10.230

${ }^{22}$ J. Prado-Gonjal, R. Schmidt, J. Espindola-Canuto, P. Ramos-Alvarez, E. Moran, Increased ionic conductivity in microwave hydrothermally synthesized rare-earth doped ceria $\mathrm{Ce}_{1-x} \mathrm{RE}_{x} \mathrm{O}_{2-(x / 2)}$, J. Power Sources, 209 (2012), 163-171, doi:10.1016/j.jpowsour.2012. 02.082

${ }^{23}$ M. Stojmenović, S. Bosković, D. Bučevac, M. Prekajski, B. Babić, B. Matović, S. Mentus: Electrical characterization of multidoped ceria ceramics, Ceram. Int., 39 (2013), 1249-1255, doi:10.1016/ j.ceramint.2012.07.055

${ }^{24}$ M. Stojmenović, S. Bošković, M. Žunić, J. A. Varela, M. Prekajski, B. Matović, S. Mentus, Electrical properties of multidoped ceria, Ceram. Int., 40 (2014), 9285-9292, doi:10.1016/j.ceramint.2014. 01.151 